\title{
Staying in the Loop: Formal Feedback Mechanisms Connecting Vocational Training to the World of Work in Europe
}

\author{
Jörg Markowitsch* and Günter Hefler \\ 3s Unternehmensberatung GmbH, Wiedner Hauptstraße 18, 1040 Vienna, Austria
}

Received: 18.04.2018; Accepted: 07.11.2018; Published: 17.12.2018

\begin{abstract}
Context: Vocational education and training (VET) is expected to be designed for creating learning outcomes which meet the needs for skills and competences in the labour market. Hence, identifying current and upcoming skill requirements and ensuring that these requirements are incorporated into education has long been the subject of academic and policy discussion. Governance processes keeping VET systems up-to-date have been more recently addressed as 'feedback mechanisms'. The term broadly summarizes the interplay of institutions, actors and processes which allows the continuous renewal of VET provision (i.e. by creating new qualifications or updating curricula). The aim of the paper is to enhance the understanding of cross-national variations in formally institutionalised 'feedback mechanisms' between VET and the labour market.

Method: The research builds on a comparative analysis of case studies in 15 European countries. The paper presents examples for four different 'formal feedback mechanisms' in Germany, France, England, and Austria.

Results: Four main types of formal mechanism have been identified: 1) The liberal model explained by VET in England and Higher VET in Austria; 2) The statist model explained by school-based VET in Austria; 3) the participatory model explained by VET in France and 4) the coordinated model explained by apprenticeship training in Germany and Austria.
\end{abstract}

Conclusions: Existing approaches in the economic sociology of labour markets, the varieties of capitalism approach as well as comparative research on welfare states are useful

${ }^{*}$ Corresponding author: markowitsch@3s.co.at

ISSN: $2197-8646$

http://www.ijrvet.net 
in predicting whether particular VET systems are likely to be predominant. However, they do not provide an alternative in describing differences in VET systems which the concept of formal feedback mechanism does. Moreover, by analysing formal feedback mechanisms, it is possible to demarcate where a VET sub-system ends and another VET sub-systems begins. In this sense research presented here also asks for new standards for comparative VET research as it suggests that entities to be compared are not countries' overall VET systems, but their potential sub-systems.

Keywords: VET, Vocational Education and Training, Vocational Education, Labour Market, Governance, Feedback Mechanism, Cross-Country Comparative Research

\section{Introduction - How to Keep VET Curricula Relevant Over Time?}

In his otherwise remarkable account of education as a social institution, US sociologist David Baker (2014) recounts an often-heard plea of the allegedly inevitable obsolescence of vocationalism. Baker sees little future for vocational education as part of secondary education and summarises accounts of its declining significance. He argues that vocational education cannot but falling behind the rising and ever-changing demands of today's economies' workplaces, which demand universal cognitive skills thought to be developed best by general schooling. Whatever vocational tracks might deliver, it cannot avoid becoming outdated soon, often even before young VET graduates enter the labour market.

Contrary to its assumed decline, vocational education has attracted much policy attention in the years after the 'Great Recession' starting in 2008 and is thought to be an effective tool in combating youth unemployment. Germany's most recent staggering economic success and its plummeting unemployment figures have moved once more the German VET system into the spotlight, after being marketed as the heart of the 'German Skills Machine' (Culpepper \& Finegold, 1999) already a decade earlier. Although disputed by a few researchers (Hillmert, 2008), the German dual system is generally regarded as an inevitable proof that initial VET can match the needs of today's world of work and even serve as powerful flywheel of innovation and competitive advantage.

The questions of program and curricula reform in general education have matured into a well-established field of research (Connelly, He, \& Phillion, 2008; Wyse, Hayward, \& Pandy, 2015). However, for initial vocational education, systematic research on reform of provision and content is relatively scarce. With the exception of a few studies on behalf of international organisations which occasionally used the term 'feedback mechanism' to describe the interplay between the labour market and the education system (Cedefop, 2009; Fretwell, Lewis, \& Deij, 2001), the concept has been hardly used. The term, which has not yet been developed into an analytical concept, broadly summarizes the interplay of institutions, actors, and processes in place aiming at the continuous renewal of VET provision (i.e. new qualifications or curricula).

This paper discusses variants of these 'feedback mechanisms' in VET across the European Union member states against the backdrop of existing typologies of VET and 
skill formation systems. For the purpose of this article 'formal feedback mechanisms' are defined as purposefully implemented formal institutional procedures, determining the particular roles of various stakeholders in planned renewal of VET provision. The term 'formal' signals that the feedback mechanisms in question have some form of legal foundation and are established on a permanent basis. It will be shown that while some types of 'formal feedback mechanisms' require particular institutional environments they represent nevertheless an independent entity with a relative autonomy vis-à-vis the overall institutional framework of VET or the political economy. This relative independence will be illustrated by showing that different VET sub-systems in one country can employ different types of 'feedback mechanisms'.

Our discussion builds on a comparative analysis of 15 European countries coordinated by the lead author on behalf of CEDEFOP (European Centre for the Development of Vocational Training) from 2012 to 2013 (Cedefop 2013). In total, 77 national and European experts were interviewed. Two types of experts were interviewed: On the one hand senior officials in ministries for education and/or employment and social partners at national leve 1 , on the other hand VET researchers at universities and national VET institutes. Interviews were conducted either in person or via telephone. A detailed guideline for the case studies was provided including a list of potential types of interviewees. Furthermore, a number of common sources (such as various Cedefop and Eurydice reports) were considered obligatory. Other sources such as white papers, regulations, laws on VET, existing national research on feedback mechanisms, on social dialogue as well as om other forms of communication and interaction in the field of VET and labour market were consulted. For this article information has been updated where required.

The paper is structured as follows: In section 2, we discuss in more detail the idea of a 'formal feedback mechanism' by comparing the more complex case of VET to reforms of curricula in general education. In section 3, we present examples for four different 'formal feedback mechanism' in Germany, France, England, and Austria, which represent all types found in the aforementioned study (Cedefop, 2013). In section 4, the identified types of formal feedback mechanisms are displayed in a more systematic manner and discussed against the backdrop of related typologies on skill formation and VET systems and conclusions are drawn for future cross-country comparative VET system research.

\footnotetext{
${ }^{1}$ For instance, in England this included interviews with representatives of the UK Commission for Employment and Skills, and the Trade Union Congress. For Germany, the Standing conference of the Ministers for Education and Cultural Affairs of the Länder; the Ministry of Education, Science, Continuing Education and Culture of the Land Rhineland-Palatinate; the German Industry Board for Vocational Training; the Industry Union Construction, Agriculture and Environment; and the Chambers of Commerce and Industry. For Austria, the Federal Ministry of Education, the Arts and Culture, and the Austrian Chamber of Commerce. For France, the Centre for Employment Studies; the Centre for Research on Qualifications and the Education Commission. 15 interviews were conducted in Germany, five in France, five in England and four in Austria.
} 


\section{The Significance of 'Formal Feedback Mechanisms' for Research on Governance in VET}

Contrary to the multifaceted curriculum research in general education, research on initial VET either adhere to a rather reductionist 'functional' perception on how education might stay in line with the needs of the world of work (see entries in Rauner \& Maclean, 2008) or pay little attention to the topic of change at all. Consequently, research on curricula development in VET is scattered, restricted to single national contexts, and has not developed into a research field in its own right. There are a number of good reasons why this is the case:

- Sheer Numbers: While most countries have one or maybe two dozen different curricula of upper secondary general education, vocational education at upper secondary or post-secondary level is much more varied, with many countries having more than 200 programmes in place.

- Standardisation: While upper secondary general education is standardised in practically all countries, for VET curricula, the canon and the expected education outcomes are standardised only in some countries. There are also countries, where VET programmes preparing for one and the same occupational field are quite distinct.

- Proximity of programmes to occupational fields/industries: Although there are differences in the degree of ownership, business interest organisations and the trade unions, often enjoy a strong say on what is going on in the particular vocational tracks relevant to their industries.

- Public funding: While general upper secondary education is mainly funded by the state, the picture is more diverse for vocational education. Some types such as the dual system of apprenticeship require strong financial contributions by the employers.

- Transitions to/usefulness for employment as one additional value: Vocational education may partake in the values of general education, provide access to further levels of education or adhere to an innate ethos of professionalism; yet, contrary to general education, vocational education by definition is designed to prepare first of all for access to the labour market and frequently, additionally to particular types of jobs in particular occupations.

In particular this last point forms the rationale of vocational education and determines its particular ideology. Vocational education therefore needs to respond to changes in what the world of work demands and simultaneously has as a knock-on effect, it actively changes how work is done. Contrary to general education, a constant and prompt change of both curricula and canon in line with the ever-changing demands of the workplaces is an essential issue for vocational education. 
For general education as for VET, there are actors - administrative units or consultative bodies - in charge of the further development and the renewal of the type of programmes, the 'time tables' and the content to be delivered. While in general education, it seems so natural that units of ministries of education oversee curricula development and that educational insiders (e.g. university experts in charge of training the next teacher generations, teachers of a particular subject) work on the "ways forward', for VET - reflecting on the arguments outlined above - other actors are natural candidates for such a task. It is one of the key arguments of this paper, that such governance processes and the way they include actors and vantage points beyond the 'small world of education', are even more vital for VET than for the more self-sustained general education.

'Formal feedback mechanisms' usually comprise important decision-making or consultation bodies (e.g. Sector Skill Councils in England or the General Council for Vocational Training, Consejo General de Formación Profesional - CGFP, in Spain, or the Trade committees in Denmark). 'Key actors', we distinguish for further analysis, include:

- 'The government/administration', as ministries of education, awarding bodies, qualification authorities

- 'The education and training providers', including schools, colleges, yet, also enterprises providing VET for their employees. Where available, umbrella organisations of education providers may have a role.

- 'The social partners', representing organised and thereby aggregated interests of the employees (trade unions; professional organisations) and the employers (chambers of trade, business interest organisations).

- 'The labour market', understood as the interplay between a set of individual employers (demanding skills) and individual workers or graduates (future workers) (supplying skills).

It is important to distinguish 'formal feedback mechanisms' as inbuilt governance structures from informal feedback processes. Various forms of informal feedback processes are found in all countries and in any arrangement of VET labour market coordination. Typical examples of informal feedback mechanisms are local school boards, alumni networks, career fairs, cooperative projects between schools and companies, and internships. These informal processes do not necessarily result in any formal changes at national level (e.g. new standards or curricula) although they can be equally or even more important to keep VET relevant for the society and the labour market than formal ones.

A second important distinction is that 'formal feedback mechanisms' need to be differentiated from procedures for 'whole sale' VET reform. Major or radical VET reforms are typically the prerogative of the responsible parliaments. In contrast, formal feedback mechanisms, inbuilt in the VET system, are expected to keep VET in line with the intentions of the original legislation and allow for the constant and planned 'renewal of VET'. In theory, the mechanism allows to sustain the quality and relevance of VET over 
time by regularly changing details. Practically, any mechanism for adjustment to changing environments might provoke 'incremental change' (Mahoney \& Thelen, 2010), as no adaptation will simply reestablish a previous state. Adaption is likely to either improve the overall setting or imply a step backward when compared to previously achieved levels of fit. Formal feedback mechanisms partly have been implemented as a 'short-cut' to time-consuming and improperly resource-demanding procedures of formal law making, where any changes of programmes or curricula would require a formal law issued by the competent national or regional parliaments.

In contrast to the functioning of formal feedback mechanisms, radical change in VET refers to changes in the foundational structures of VET, implying a fundamental change of actors, roles, funding, procedures, hierarchies of programmes, and outcomes. In this sense radical change usually describe a system change or an extension to an existing system. Western Europe, for example, has seen a series of radical VET reforms in the late 1960, when today's legal base of VET has been formulated, for example, in Germany and Austria (Busemeyer, 2009), (Graf, Lassnigg, \& Powell, 2012). The introduction of the 'baccalauréat professionnel' (Bac Pro) in France in 1985 or the 'Berufsmatura' (an external exam providing general access to higher education for skilled workers) in Austria in 1997 are other examples of VET reforms not forming part of any feedback mechanisms as understood here.

\section{Four Types of Formal Feedback Mechanism Identified in Europe}

In the following chapter, we present examples for four different models of formal feedback mechanisms in four different countries: Austria, France, England and Germany. Furthermore, for Austria we demonstrate the co-existence of three different models of feedback mechanisms in three different subsystems of VET: higher VET, the dual system and school-based VET.

\subsection{The Liberal Model: VET in England and Higher VET in Austria}

The 'liberal' model of feedback mechanism relies strongly on what might be perceived as an ideal type education market of (individual) 'sellers' and 'buyers'. Even in absence of a formal institution, it is assumed that VET providers are able to respond to the needs of the labour market in a direct and non-mediated way: Insofar as VET programmes meet the needs of employers, they are also sought after by learners who value the competitive advantage in the labour market provided by the well-matched qualification. The state's role in these educational markets is a restricted one, setting the rules for (co-)funding and competition, yet, refraining from any intervention in the types of programmes offered or the curricula taught. However, when public money is involved, there is also an interest in quality assurance of the provision. Therefore, the presence and frequent change of various institutional quality assurance requirements accompany market-centered approaches to VET. 
The liberal feedback mechanism as such intends to improve the functioning of the market-based approach by requiring (1) some systematic reporting on market processes to demonstrate that the educational supply actually meets the aims of the learners and the demands of the employers and (2) by giving voice to single market players, typically representatives of individual enterprises, who are thought as being able to report firsthand insight on on-going changes in their industries. The liberal feedback mechanism does not foresee any strong role for organised interest groups. Moreover, it is not set up to provide strong guidance to the field, yet, simply adds to the functioning of the informal market mechanisms (compare Figure 1).

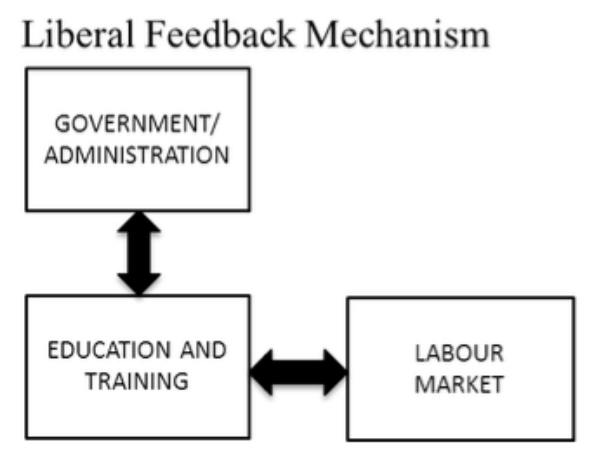

\author{
Characteristics: \\ - ,education market ${ }^{*}$ \\ - state ensures quality by external \\ agencies \\ - state sets rules for (co-)funding and \\ competition \\ - content/design of programmes \\ determined by providers
}

Figure 1: The liberal type of feedback mechanism and its characteristics

Source: Authors

We find a combination out of a market-based approach and forms of 'liberal feedback mechanisms' in many industrialized countries in the area of continuing vocational education and training (CVET), where the state's role is limited and for which firms or individuals pay the lion's share. While it is the standard model for CVET it is interesting to see in which other areas it appears. For this purpose, we use the example of initial VET (IVET) in England and Higher VET in Austria.

In England, upper secondary VET is generally provided within a highly multifaceted further education sector, which caters both for young people preparing for entry to the labour market, and adults, who intend to extend their qualifications, often combining part-time work with education. As such the further education sector is the major provider of post-compulsory IVET. Providers shape their programmes in accordance with established professional norms (and often in cooperation with professional organisations) and the perceived needs of students and employers. In the absence of state regulation, IVET providers tend to conform to professional patterns of good practice established among the educational organisations in their field.

A distinctive feature of the English system is the plethora of qualifications, providers and individual awarding bodies (Wolf, 2011). With such a multitude of IVET providers rather than a regulated number of state-controlled schools or colleges - 'transparency instruments' are needed. Governance of IVET is implemented via the definition and renewal of occupational standards on the national, sectoral, or regional level. IVET 
providers are expected to conform to these standards. A number of agencies are involved in the formulation and renewal of IVET. One such agency is the UK Commission for Employment and Skills (UKCES). The UKCES plays an important role in leading the VET policy agenda and oversees the development of the Sector Skills Councils (SSCs) by regulating operating licenses (UKCES, 2011). The UKCES operates on a 'social partnership' basis with representation of businesses, the public sector, and trade unions on the Board. The Office of Qualifications and Examinations Regulation (Ofqual) is primarily responsible for overseeing the quality of IVET. Ofqual ensures that qualifications, examinations, and assessments provide the basis for future progression of all learners. Ofqual regulates and monitors organisations that award qualifications. The SSCs determine which awarding bodies are able to offer a qualification. To receive SSC approval all units in a qualification must be directly related to a specific National Occupation Standard (NOS), which are developed by the SSC to reflect current employer requirements. Qualifications must also comply with the requirements of the Qualifications and Credit Framework to be approved by an SSC, and therefore to be eligible for Ofqual accreditation.

The Sector Skills Councils (SSCs), introduced in 2003, are the latest attempt to add a 'formal feedback mechanism' to the market-focussed approach. The SSCs are voluntary, employer-led coordinating bodies that aim at improving the coordination with regards to IVET and skills supply between employers in a single sector and between employers and educational service providers catering for a sector's particular needs (see also European Commission \& Ecorys, 2010). Sector Skills Councils are licensed private bodies, supported by core groups of sectoral employers which aim to promote the active participation of relevant enterprises in their work, and which until 2010 received grants to assist in this process (Funding rules have drastically changed since 2010, as councils have to apply for project money in competitive procedures instead of receiving a lump sum funding). Core tasks of SSCs include labour market intelligence, the promotion of company training, the creation and support of modern apprenticeship schemes, and actively contributing to the formulation and incremental improvement of occupational standards relevant for the sector, usually in close cooperation with established bodies responsible for formulating occupational standards. Typically, councils are responsible for contributing to high numbers of occupational standards for particular activities. Based on updated standards, training providers are expected to implement any changes on their own, and moreover, provide the framework for IVET qualifications. SSCs are responsible for organising employer-led feedback on changing occupational standards, training and apprenticeship projects - including input from various employers and further education providers. This should increase cooperation within the sector, leading to mutual learning and the development of more shared practice. By 201523 Sector Skill Councils and Bodies had been established, and had survived an evaluation and re-licensing process.

Up to now evidence on the effectiveness of SSCs has been mixed (Payne, 2008; Payne \& Keep, 2011). Typically, due to the voluntary basis on which they operate, the councils reach out only to a small minority of organisations in their sector (House of Commons: business innovation and skills committee, 2012). Furthermore, SSCs tend 
to fail in representing their sector as a whole or achieving interest aggregation for larger shares of the enterprises in the sector. Consequently, they are unable to play a role similar to the one of sectoral business associations in coordinated market economies (see below).

Although situated in a completely different institutional environment, we can find the logic of combining a market-driven approach with a liberal feedback mechanism also in a specific part of the Austrian education system, namely in higher vocational education. In contrast to universities, universities of applied science (Fachhochschulen), which only started in the mid 1990ies aim at providing a research-grounded vocational qualification. This implies that programs are tailored to specific occupational fields. Periods of work placement form a mandatory part of the bachelor curriculum. Programs are developed, in their majority, by non-public (although publicly funded) not-for-profit providers. They are subject to a specified accreditation and evaluation procedure by the Agency for Quality Assurance and Accreditation Austria (AQ Austria) which oversees also public and private universities (Bernhard, 2011). Social partners are represented in the AQ Austria and are therefore involved in the review and approval procedure of applications to set up study courses and their quality assurance, but they have only a minor role. The minister for education supervises the agency and decides upon financing of study programs.

The demand for a new study course or the change of existing education and training content is frequently expressed by single local companies, business interest groups of a sector, sector specific organisations of the Austrian Economic Chambers or other occupational and sector specific associations. Impulses also come directly from federal states and municipalities. Finally, the providers themselves have a strong incentive to 'screen the market' for new ideas and examples and develop new programs in order to receive state funding; in this point, their situation strongly resembles the situation of providers in the further education sector in England. The feasibility of the planned curriculum and the overall concept of the programme need to stand the test of a particular form of survey-based evaluation. In the evaluation, both potential future employers and potential participants need to confirm that the programme can be expected to meet the needs of the labour market and to attract a sufficiently large student body. This feasibility study also forms part of the application for the accreditation of the programme (Messerer, Markowitsch, Sohm, \& Balfe, 2006). The application has to be addressed to the AQ Austria, which in a board meeting decides upon the approval.

As in the case of IVET qualifications in England, for the Austrian approach in the field of higher VET, we can speak of an education market in which the state ensures the quality of the provision by an external agency and provides funding. The specific design of the qualification, in terms of its content, is left to the providers and their direct interaction with labour market representatives.

\subsection{The Statist Model: School-based VET in Austria}

In a majority of countries where initial vocational education is state-funded, state-run, and state-controlled, variations of the statist model of feedback mechanism can be found. 
In these countries, the feedback mechanism consists typically in the form of a board, a committee, or a temporary working group, established by the ministry of education and responsible for developing new curricula or educational standards. Actors represented include experts from various fields: the schools (e.g. school principals, experienced teachers in a particular subject), researchers, various governmental bodies, non-governmental organisations, and the corporate world. However, the decision to change curricula ultimately lies with the responsible department of the ministry. Individual actors on the boards are invited to participate based on their expertise. The initiatives can come either from the ministry itself, or from certain schools pooling their interests or strong single actors, e.g. large manufactures or professional associations. Often, initial proposals are rather vague, and of the type 'something has to be done' or 'it is about time for a change'.

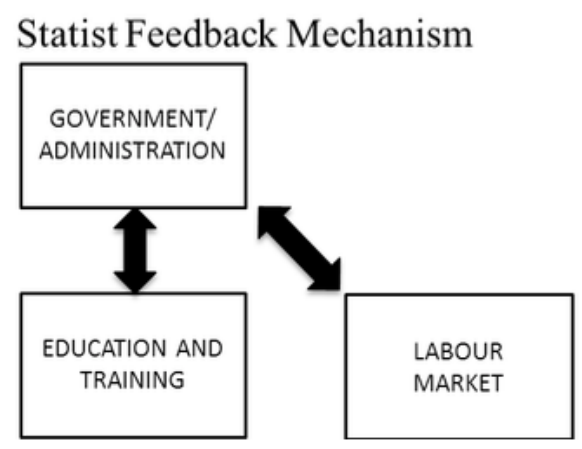

\author{
Characteristics: \\ - state funds and controls \\ - content determined by temporary \\ working groups/commissions set up by \\ ministry of education \\ - initiatives for changes ad hoc, not \\ systematically \\ - only informal role of social partners
}

Figure 2: The statist type of feedback mechanism and its characteristics

Source: Authors

We take the example of school-based VET in Austria to illustrate the statist feedback mechanism (see Figure 2). School-based vocational education makes up almost 40 per cent of a youth cohort and half of all participants in vocational education in Austria. There is a large variety of higher-level VET colleges and corresponding VET schools in various technical domains, and in fields such as business administration, tourism, or agriculture. While enjoying some autonomy, schools follow compulsory national curricula, which are fundamentally updated only over a long period of time (about 10 to 15 years). However, smaller changes can be implemented at short notice. Specialised Administrative Units (Fachabteilungen) within the Ministry of Education are responsible for particular occupational fields and its VET colleges and schools.

While there are some more regular opportunities for exchange (e.g. yearly conferences), interaction with organised interest groups is not formalised and the collection of feedback from employers and employees takes place only informally. Senior teachers of vocational subjects and school principals, who are in a constant exchange both with one another and the Fachabteilungen, are another important source for information. VET teachers become aware of new and changing requirements in the world of work through 
their interaction with firms on the local and/or sectoral level via research projects and compulsory internships undertaken by students, or through their own personal networks. However, it is the responsibility of the Fachabteilungen to draw conclusions and take concrete steps forward to update curricula. When a firm believe is articulated, that change needs to be implemented, proposals are developed by commissions (Lehrplankommission) consisting of VET teachers representing all relevant regional VET schools. Typically, a series of forums and conferences support the exchange process with social partners, sector experts, and individual firms. Participation of any actors within the 'Lehrplankommission' beyond the Fachabteilung and VET teachers is voluntary and hints given remain informal. However, even in absence of a formal role, the strong influence of Austrian social partners on curricula reform must not be underestimated. Beyond informal participation in the preparation of regulation on curricula, recognised social partners typically enjoy the right to consultation on any formal regulation prior to implementation (Cedefop, 2013; Henkel \& Markowitsch, 2005).

Attractiveness of school-based VET in Austria has steadily increased over the past two decades, attracting as many students as the long-time dominating apprenticeship sector (see below). The equal importance of two modes of VET on upper secondary level has motivated several observers to call the Austrian IVET approach a 'hybrid system' (Busemeyer, 2013; Graf, 2013; Graf et al., 2012), Previous typologies of VET have categorised Austria's VET system alongside the German one as dual (apprenticeship type). However, it is crucial to recognize that the Austrian apprenticeship system and school-based VET form two distinct sub-system of IVET with distinct and independent feedback mechanisms. The statist model of feedback mechanism also exits in Germany in the school-based VET sector, in parallel to the coordinated model of the dual system (see below). The list of countries where (mainly) statist feedback mechanisms in VET have been identified further includes Bulgaria, Estonia and Sweden.

\subsection{The Participatory Model: France}

The statist model is certainly the most frequent model of feedback mechanism in VET at upper-secondary level in Europe. As described in the previous section for school-based VET in Austria, in the statist feedback mechanisms, social partners may be consulted in an informal ad hoc way to contribute to reform processes. However, in other cases social partners may have a more distinct and clearly shaped role, and they are consulted at different stages in the change process and on various tasks, including the definition of VET curricula or standards. This is for instance the case in France, Hungary or Finland, and it is an important variation of the statist model. Although the VET systems in these countries can also be characterised as 'state-regulated' or 'statist', the role of social partners on VET is much more pronounced as in states with a 'statist feedback mechanism' as in Bulgaria or Estonia. We therefore suggest to distinguish a participatory model of feedback mechanisms (with more formalised influence of social partners) from the statist model of feedback mechanism (with only informal roles for the social partners) described in the previous section.

VET in France provides a good case for a VET system with a feedback mechanism demonstrating the participatory model (see Figure 3). IVET in France is centralised and embedded in the comprehensive education system in which the state has sole responsibility for content of curricula and examinations (Ogunleye, 2011). 


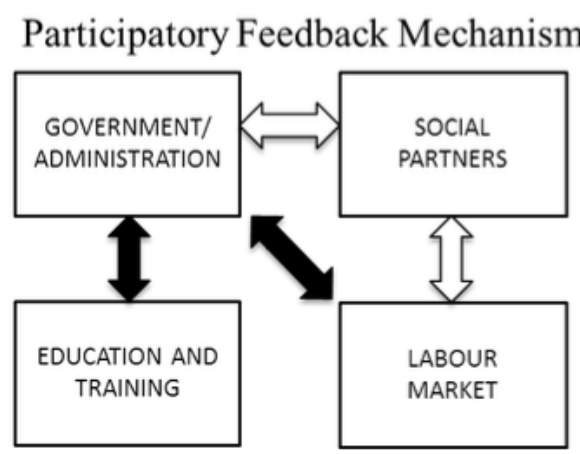

\section{Characteristics:}

- similar to statist type (state is reponsible for curricula and examinations), but

- formal, consultative role of social partners

Figure 3: The participatory type of feedback mechanism and its characteristics

Source: Authors

Apprenticeship training (undertaken by less than one third of all VET students) is considered to be an integral part of IVET, while participation in VET in general is modest and only comprises approximately one third of the entire student population.

There are two IVET streams in France which can be distinguished. On the one hand, a 'technological stream' prepares students to go to higher technological education after the technological baccalauréat in order to obtain a degree at ISCED 5 level in two years in an Institute Universitaire de technologie (IUT) or in a post-baccalauréat class of a high school, Section de Technicien Supérieur (STS). On the other hand, a 'vocational stream' prepares students to enter the labour market either in two years after a certificat d'aptitude professionnelle (CAP), in three years after a vocational baccalauréat in a vocational high school (lycée professionnel) or through apprenticeship (Michel \& Looney, 2015).

There are almost 200 specialities of CAP and around 80 specialities of vocational baccalauréat. These are defined and updated every five years by the public authorities in co-operation with trade unions and employers' associations within so-called consultative professional commissions (Commissions Professionnelles Consultatives or CPC). Within the Ministry of Education there are $14 \mathrm{CPC}$ corresponding to broad sectors of economic activity (for example: metallurgy, food industry, tourism), but CPCs are also run by other ministries. Each CPC has 40 members of four categories: ten representatives of trade unions, ten representatives of employers' associations, ten representatives of public bodies and ten individuals selected for their specific expertise (personnalités qualifiées) $\left.\right|^{2}$ Each CPC is responsible for assessing the need for (new) qualifications, preparing qualifications including a lists of the subjects to be incorporated, outlining the structure and organisation of examinations and the preparation and dispatching of documentation to the Minister for National Education for approval (European Commission \& Ecorys, 2010).

\footnotetext{
${ }^{2}$ http://eduscol.education.fr/cid46815/nouvelle-architecture-des-cpc.html (7.11.2016).
} 
Although the French state has the leading role in the overall development of VET, the CPCs and the active role given to the social partners in the body play an increasingly important role in awarding national qualifications and the creation, updating and design of related referential standards for specific economic sectors. Nevertheless, this moderate influence of social partner on the renewal of VET provision needs to be distinguished from systems in which social partners are more or less in charge of the system, as we will see for the 'coordinated model' of feedback mechanism in the next section. Furthermore, it must be seen in the general context of national employment relations and governance which Saurugger characterises for France as follows: 'French state authorities are generally much less enthusiastic about involving private interests in public policy formulation than their Austrian or German counterparts. The bureaucracy in countries characterized by statism, such as France regards the influence of interest groups as illegitimate. It has traditionally used its formal consultation process more as a way of gathering information than as an opportunity to incorporate organized interests.'(Saurugger, 2007, p. 122)

\subsection{The Coordinated Model: Apprenticeship Training in Germany and Austria}

The coordinated feedback mechanism is characterized by the decisive and far-reaching role of organised business and organised labour in the renewal processes of VET. Initiative to renew VET content typically comes from business interest organisations, with large employers as visible spokesmen in favour of a reform or from trade unions that are able to highlight specific issues and problems relating to the labour market. These demands are mediated by the social partners and expressed to the government in the form of proposals. The government then takes the formal decision on any change. The implementation of change again depends largely on the social partners who are responsible for major parts of the provision (e.g. apprenticeship places, training of trainers, assessment, etc.). For an illustration of the coordinated model of feedback mechanism see Figure 4, for a detailed representation for the German dual system see Figure 5.

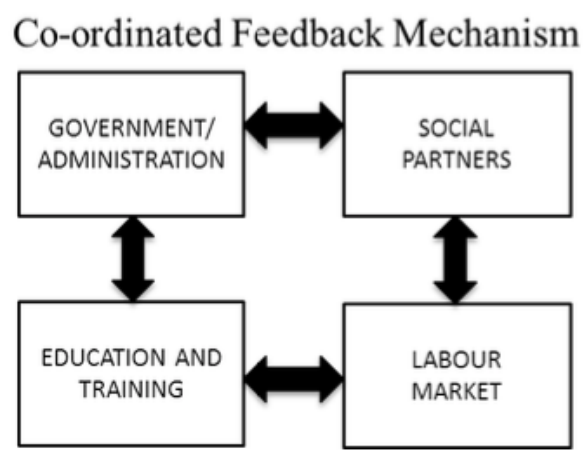

\section{Characteristics:}

- Largely co-funded by employers and managed by social partners

- content of curricula and examinations largely determined by social partners

- initiatives for change typically come from (or are mediated by) employer organisations and trade unions

Figure 4: The coordinated feedback mechanism and its characteristics

Source: Authors 
In Germany, the dual system, which combines company-based learning with learning in vocational schools, is the predominant form of education at upper secondary level. Around half of a youth cohort chooses each year one out of approximately 350 recognised training professions; some opt for full-time vocational schools, which are offered in various domains. Only roughly a quarter of a cohort continues their studies in the 'Gymnasium' leading to a general higher education entrance qualification (Autorengruppe Bildungsberichterstattung, 2016, p. 80). In addition, a growing part of graduates of academic upper secondary education enter dual VET after completion of this academic track (BIBB - Bundesinstitut für Berufsbildung, 2016, p. 161).

For apprenticeship training the vocational competences to be acquired are established in so-called training regulations (Ausbildungsordnungen), which are accompanied by a framework curriculum (Rahmencurriculum), developed in line with regulation for every recognised training profession. The motivation and initiative for an amendment to training regulations or development of new ones (together with the framework curriculum) usually comes from the social partners addressing one or several professions within a branch. The organisation and supervision of the renewal of training regulations is managed by the Federal Institute for Vocational Education and Training (Bundesinstitut für Berufsbildung, BIBB) on behalf of the federal government. The Standing Conference of the Ministers of Education and Cultural Affairs of the Länder (Kulturministerkonferenz, KMK) is simultaneously responsible for organising and supervising the framework curricula. (The Standing Conference unites the ministers and senators of the Länder responsible for education, higher education and research, as well as cultural affairs since the end of WWII.) Thus, the feedback mechanism of the dual VET system consists of two independent parts that work in parallel.

The development of the new training regulations and framework curricula takes approximately one year. There are three basic stages in developing new training regulations and framework curricula: the preliminary phase, where the social partner organisations have to come to a first agreement before contacting the competent ministries; the development and agreement phase, organised by BIBB and KMK; and the promulgation phase, with votes and control mechanisms before the official issuing of the new training regulation/framework curriculum. On the one hand stakeholders involved in these processes complain that the whole renewal process (from initial concept of an alteration to a training regulation to implementation) is too long and too slow to react to urgent labour market needs, as it can take up to two years and sometimes even longer. The time taken is caused by the involvement of a large number of committees, panels, boards or bodies that represent employers and employees in the preliminary phase. On the other hand, they see the involvement of a large number of committees, panels, boards and bodies that represent employers and employees in the preliminary phase as strength. Solving this paradox and mediating the needs of specific employers while at the same time ensuring that graduates can practice their occupation everywhere in the market is at the heart of the coordinated model.

In principle, the Austrian feedback mechanism for renewing occupational profiles in the Austrian apprenticeship system is very similar to the German one (Cedefop, 2013; Henkel \& Markowitsch, 2005). The actual design of in-company curricula is primarily conducted by the tripartite Federal Advisory Board on Apprenticeship (Bundesberufsausbildungsbeirat). The Board is equally composed of representatives of the social part- 


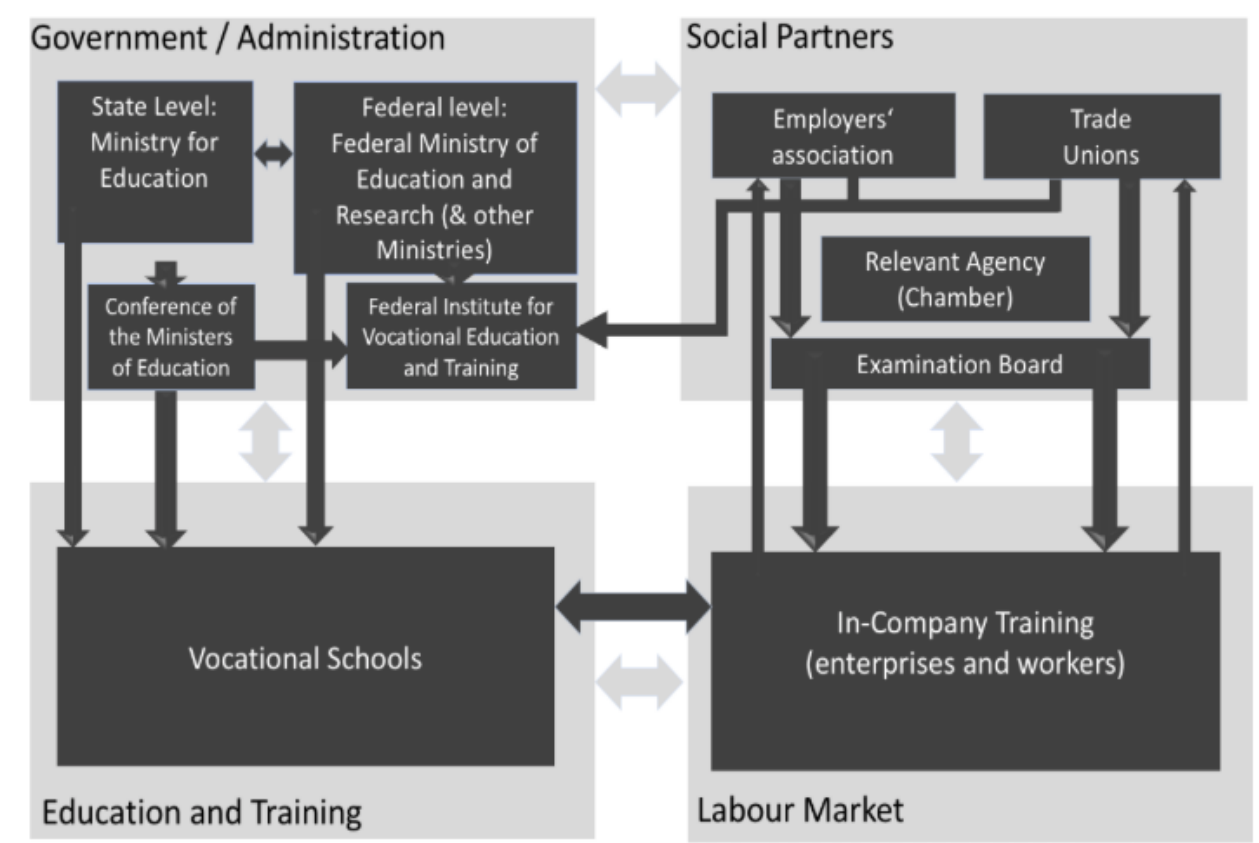

Figure 5: Feedback mechanism of the German dual system

Source: Authors, see also (Cedefop, 2013)

ners, i.e. six board members as well as one chairperson each proposed by the employers' and employees' organisation. Furthermore, the ministry of education appoints two consultative board members among VET teachers. The board's subcommittees or the educational research institutes of the social partners introduce proposals or draw upon expert opinion concerning reform proposals, e.g. on the introduction of new or modernisation of existing apprenticeships. These draft proposals are distributed to all relevant employer associations (including the public sector and other actors). Internal discussions are conducted and once consensus is reached the Board submits the proposal for official approval to the ministry of Economy, which is responsible for the company related part of the apprenticeship. As in the case of Germany the school part is administered in parallel by the ministry of Education, but this process is perceived by stakeholders as subordinated.

Although many commonalities can be identified between countries, which adopt this model and system of vocational training, there are also differences which make a comparison interesting. For example, there is a contrast between the stronger sectoral arrangements, which can be found in Denmark and the Netherlands in the form of (autonomous) trade committees or sector skill councils, and the influential umbrella organisations of chambers present in Austria and Germany. Rauner and Wittig (2013) also found remarkable differences as regards the degree of fragmentation and standardization for the apprenticeship systems in Austria, Denmark, Germany and Switzerland. 


\section{Discussing Feedback Mechanisms within the Scope of Cross-Country Comparative VET Research}

The above descriptions of feedback mechanism operating in VET subsystems in England, Austria, France and Germany are only summaries of more elaborated case studies (see Cedefop 2013). Nevertheless, these cases allow to demonstrate four fundamentally different models of feedback mechanism by focusing on one crucial question: How is the content of vocational education and training in terms of qualifications, programmes and/or curricula renewed by the help of formal institutionalized mechanisms?

In the following, we summarise the four types of formal feedback mechanism and discuss them against the backdrop of selected typologies describing either the wider institutional environment of a form of political economy or the VET and skill formation systems. The four types foresee - a different number of - actor positions representing either 'education', the 'labour market' or the 'state' and enables particular ways of interaction between them (see Figure 1). All identified models allow for some exchange and thereby feedback between the education and training providers and the labour market, as illustrated, yet the roles of 'government' and 'social partners' work out differently in the mediation of the exchange. Clearly, the models presented in Figure 6, deliberately simplify existing arrangements, as one can see, for example, when comparing the formal feedback mechanism of the German Dual system (represented in Figure 5 above) with the generic representation of the coordinated model in Figure 4.

In the liberal model, the education and training providers collect and systematize the responses of both individual employers and future or former students. Consequently, they justify their provision and the programmes, curricular and taught canon vis-à-vis the (co-)funding 'government/administration' by the evidences collected. Moreover, given that they typically receive funding per study place and not a mere lump sum, they depend on the actual willingness of students (and enterprises) to rely on their services. The difficulty is that training providers need to respond to a strongly diversified demand, as patterns of organising work and thereby the skills demanded might know a high number of variations. It is important to note, that the government itself does not systematically review changing demands in the labour market, yet, rely on the information education providers submit as justification for updating their provision. In the 'liberal' feedback mechanism, the social partners have no say and therefore aggregated interests of either the employers or the employees are missing. In the case of VET in England, the absence of social partners reflects the weak position of organised labour and the non-existence of any strong interest organisations of the employers in many sectors. However, as the case of the liberal feedback mechanism in the Austrian university of applied science sector demonstrates, social partners' influence could be marginal in a formal feedback mechanism even in countries, where they typically play a significant role.

The 'statist' model is characterised by strong state regulation of vocational education. Educational providers typically work within a closely out-spelled framework for their provision, yet, the formal feedback mechanism has no exchange with any labour market actors. The government/administration itself organises a review of changing market needs, applying varying techniques, and build their decisions on the update of VET provisions on the outcomes of research results and collected opinions. The 'statist' 
feedback

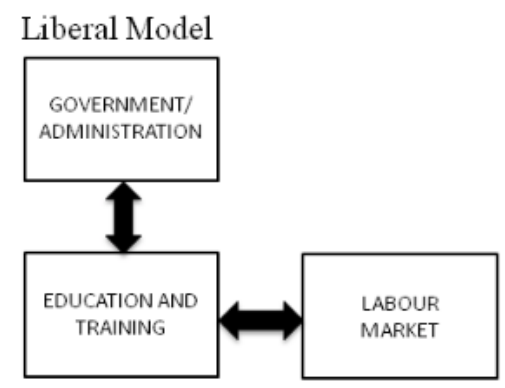

Participatory Model

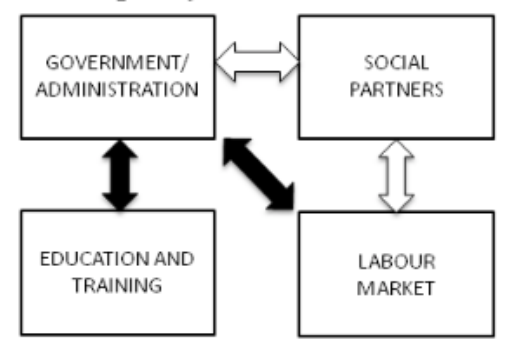

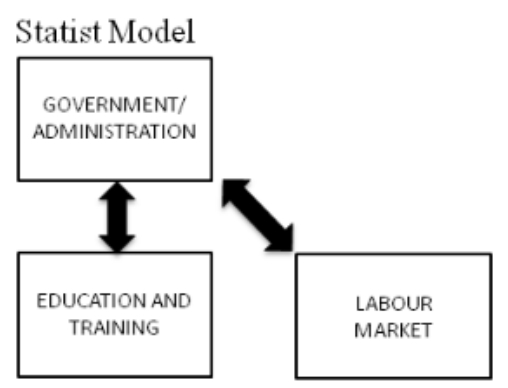

Co-ordinated Model

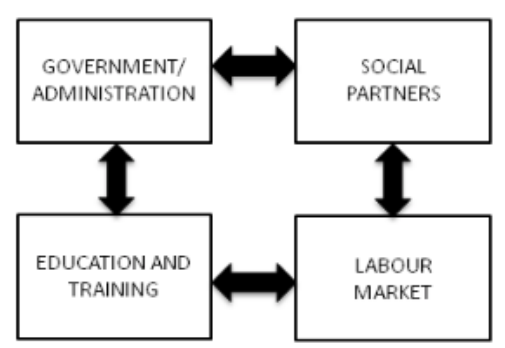

\section{Country Examples}

Liberal Model:

IE, UK

Statist Model:

BG, EE, PL and

school-based VET in

$\mathrm{DE}, \mathrm{AT}$ and SE.

Participatory Model: ES, FR, HU, FI and dual VET in SE

Co-ordinated Model:

DK, NL, SI and

dual VET in DE, AT

Figure 6: Main types of feedback mechanism identified in IVET systems in Europe

Source: Authors, see also (Cedefop, 2013); white arrows indicate the modest influcence, while black arrows show main interaction

mechanism' provides no space for the 'social partners' and thereby lack the benefits from social partner's capacity of interest aggregation across a variety of enterprises and groups of employees and weak links between education and the labour market. A basic type of 'statist' feedback mechanism can be found most European countries. However, they are more likely to be found in systems, which clearly focus on state-regulated, school-based VET (e.g. Bulgaria, Estonia, Sweden, see Cedefop 2013).

The 'participatory' model follows closely the characteristics of the 'statist' model, yet, foresee a consultative role for the social partners. Organised interests could thereby articulate particular needs and reform proposals on a regular base and partake in the governance of the VET sector. However, their role remains limited when compared to the coordinated model, where the social partners effectively control key institutions in charge of providing VET and updating VET curricula. So, by simply adding the social partners voice, one cannot expect to achieve the particular strengths of a coordinated feedback mechanism. Besides France, the participatory model was identified for VET in Spain, Hungary and Finland.

In the 'coordinated' type of formal feedback mechanism, the social partners are the drivers of renewal processes. Typically, they are also partly responsible for the implementation of any reform of programmes, curricula or canon achieved. The social 
partner's strong role relies on their capacity to aggregate diverging interests within their camps, i.e. organising the diverging interests of employers on the one hand, the diverging interests of various groups of employees on the other hand in a way, that meaningful compromises with regard to VET provision is possible. The outcome of the compromises, consequently, can make a difference in the sectors, for which they have been successfully negotiated. For the coordinated feedback mechanisms to work, a particular institutional environment is required, which is well captured by the concept of 'collective skill formation system' (Busemeyer \& Trampusch, 2012). Besides the dual VET in Austria and Germany this model was identified for VET in the Netherlands and Denmark and to some extent also Slovenia.

How does the concept of formal feedback mechanism add to existing approaches of comparing VET or skill formation systems? What is its added value and what are the limits of the concept?

Firstly, formal feedback mechanisms are anything but invisible as often claimed for informal institutional or cultural processes. Despite their legal base, however, they escape the scrutiny even of experts on a particular VET system. As there are little traditions to describe them systematically and in a comparable, and tangible way, they remain outside the attention of the policy and research communities. By adopting a more structured approach in describing formal feedback mechanism, we can clearly describe the actors involved and processes implemented, leading up to the renewal of VET programmes, curricula or standards.

Secondly, approaches developed in the economic sociology of labour markets, the varieties of capitalism approach as well as comparative research on welfare state are useful in predicting whether particular VET systems are likely to be predominant. However, they do not provide an alternative in describing differences in VET systems. Not only because, they use VET as explanatory variable and are not interested in the difference of VET systems as such, but because they necessarily have to be wrong or inaccurate when describing VET, because they need to take a country's whole education system as research entity and do not acknowledge the difference between types of VET provision within a country. This leads to misinterpretation as for example by ignoring differences between VET in the French and Italian speaking part of Switzerland as pointed out by Gonon (2004) or as we have shown by ignoring the importance of school-based VET in Austria, which at least makes up half of overall enrollment in VET.

Thirdly, the concept of formal feedback mechanism is able to grasp constitutive elements of a VET system without extensive reference to traditional education system characteristics or an extensive analysis of the institutional environments. Moreover, by analysing formal feedback mechanisms in place, it is possible to demarcate where a VET sub-system ends and another VET sub-systems begins. In this sense research presented here also asks for new standards for comparative VET research as it suggests that entities to be compared are not countries' overall VET systems, but their potential sub-systems, and their particular formal feedback mechanism. 
Table 1: Comparing the concept of feedback mechanism with concepts of skill formation and VET systems

\begin{tabular}{llll}
\hline Concepts & $\begin{array}{l}\text { Skill formation regime } \\
\text { (Busemeyer \& Tram- } \\
\text { pusch, 2012) }\end{array}$ & $\begin{array}{l}\text { VET-System } \\
\text { (Greinert, 2004) }\end{array}$ & $\begin{array}{l}\text { Feedback } \\
\text { mechanism }\end{array}$ \\
\hline England & Liberal & Liberal & Liberal \\
France & Statist & Statist & Participatory \\
Germany & Collective & Dual & Coordinated \\
Austria & Collective & Dual & $\begin{array}{l}\text { Coordinated } \\
\text { (apprenticeship) }\end{array}$ \\
& & & Statist \\
(school-based VET) \\
\end{tabular}

Source: Authors

So far, little comparable evidence is available on the degree of effectiveness of the various types of feedback mechanisms and its variations when implemented in different institutional environments. It can only be assumed that each type of formal feedback mechanism has its particular merits and shortcomings. Moreover, even in one country, the very same feedback mechanism may work for one particular VET field, yet fail in others. When listening to experts in the field, we got the firm impression that a feedback mechanism's specifications might not be able to guarantee the desired outcome, yet, that outcomes depends heavily on its implementation and the politics applied by the involved parties. It would be therefore no surprise that one and the same, yet, differently implemented and enacted feedback mechanism could create desirable outcomes in one case and poor ones in others. Moreover, institutional context matters and types of feedback mechanisms are likely to be complementary to particular other institutions, notably industrial relations. Yet, as the Austrian higher VET example shows, one type of formal feedback mechanism might work considerably well even in environments where it represents a kind of least likely case.

We have shown that formal feedback mechanisms in VET are a necessary and promising unit of research. However, more work is required to study the various mechanisms in a more detailed way, investigating their year-to-year functioning, studying their responses to changing political environments (composition of government), to the changing composition of cohorts of young people and their educational preferences, and to changing economic circumstances (structural changes in the economy; booms and busts in sectors or the economy as a whole). By extending our knowledge about the workings of formal feedback mechanisms, we could spell out better how today's advantageous characteristics of VET in many European countries could be preserved or even further improved over time. Only by 'staying in the loop' and renewing VET provision in the right ways and 'on time', VET can stay a promising option. 


\section{References}

Autorengruppe Bildungsberichterstattung. (2016). Bildung in Deutschland 2016 ein indikatorengestützter Bericht mit einer Analyse zu Bildung und Migration. Bielefeld: wbv.

Bernhard, A. (2011). Quality assurance on the road: Finland and Austria in comparison. European Educational Research Journal, 10(4), 583-594.

BIBB - Bundesinstitut für Berufsbildung. (2016). Datenreport zum Berufsbildungsbericht 2016. Informationen und Analysen zur Entwicklung der beruflichen Bildung. Bielefeld: W. Bertelsmann Verlag.

Busemeyer, M. R. (2009). Wandel trotz Reformstau: die Politik der beruflichen Bildung seit 1970. Frankfurt am Main: Campus-Verlag.

Busemeyer, M. R. (2013). Die politische Ökonomie kollektiver Ausbildungssysteme im internationalen Vergleich. In M. Stock, A. Dietzen, L. Lassnigg, J. Markowitsch \& D. Moser (Eds.), Neue Lernwelten als Chance für alle. Beiträge zur Berufsbildungsforschung. Innsbruck-Wien: Studienverlag.

Busemeyer, M. R., \& Trampusch, C. (2012). The Comparative Political Economy of Collective Skill Formation. In M. R. Busemeyer \& C. Trampusch (Eds.), The Political Economy of Collective Skill Formation (pp. 3-38). Oxford: Oxford University Press.

Cedefop. (2009). The dynamics of qualifications: defining and renewing occupational and educational standards. Luxembourg: Publications Office of the European Union.

Cedefop. (2013). Renewing VET provision. Understanding feedback mechanisms between initial VET and the labour market. Luxembourg: Publications Office.

Connelly, F. M., He, M. F., \& Phillion, J. (2008). The SAGE handbook of curriculum and instruction. Los Angeles/London: SAGE.

Culpepper, P. D., \& Finegold, D. (1999). The German skills machine. Sustaining comparative advantage in a global economy. New York/Oxford: Berghahn.

European Commission, \& Ecorys. (2010). Sector councils on employment and skills at the EU level: a study into their feasibility and potential impact.

Fretwell, D., Lewis, M. V., \& Deij, A. (2001). A framework for defining and assessing occupational and training standards in developing countries. World Bank, Human Development Network Education Department, Human Development Sector UnitEurope and Central Asia Region.

Gonon, P. (2004). The dynamics of vocational training innovation in Switzerland. In W.D. Greinert \& G. Hanf (Eds.), Towards a history of vocational education and training (VET) in Europe in a comparative perspective: proceedings of the first international conference October 2002, Florence. Volume I, The rise of national VET systems in a comparative perspective. (Vol. 103, pp. 88-99). Luxembourg: Office for Official Publications of the European Communities. Graf, L. (2013). The hybridization of vocational training and higher education in Austria, Germany, and Switzerland: Budrich UniPress.

Graf, L., Lassnigg, L., \& Powell, J. J. W. (2012). Austrian Corporatism and Institutional Change in the Relationship between Apprenticeship Training and SchoolBased VET. In M. R. Busemeyer \& C. Trampusch (Eds.), The Political Economy of Collective Skill Formation (pp. 150-178). Oxford: Oxford University Press.

Greinert, W.-D. (2004). European Vocational Training Systems. Some Thoughts on the 
Theoretical Context of Their Historical Development. European Journal: Vocational Training, 32, 18-25.

Henkel, S., \& Markowitsch, J. (2005). Analyse der Kommunikationsprozesse in vier Berufsbildungsteilsystemen. In Lassnigg, L. \& J. Markowitsch (Eds.), Qualität durch Vorausschau. Antizipationsmechanismen und Qualitätssicherung in der österreichischen Berufsbildung (pp. 31-75). Innsbruck: Studienverlag.

Hillmert, S. (2008). When traditions change and virtues becomes obstacles - Skill formation in Britain and Germany In K. U. Mayer \& H. Solga (Eds.), Skill Formation - Interdisciplinary and cross-national perspectives (pp. 50-81). Cambridge: Cambridge University Press.

House of Commons: business innovation and skills committee. (2012). Apprenticeships: fifth report of session 2012-13 (Vol. Vol. 1). London.

Mahoney, J., \& Thelen, K. (2010). A theory of gradual institutional change. In J. Mahoney \& K. Thelen (Eds.) Explaining institutional change: Ambiguity, agency, and power, (pp. 1-37.), New York: Cambridge University Press.

Messerer, K., Markowitsch, J., Sohm, K., \& Balfe, W. (2006). Quality Assurance in a System Perspective. Good practice from the Irish VET and the Austrian HE sector. In Federal Ministry of Education Science and Culture (Ed.), Quality in Eduaction and Training (pp. 43-57). Vienna: Federal Ministry of Education, Science and Culture.

Michel, A., \& Looney, J. (2015). Certification of informally acquired competences in France. Background report conducted for a Bertelsmann Foundation Study on Recognition of Informal and Non-formal Learning.

Ogunleye, J. (2011). Preparing learners for the workplace in Europe: vocational education and training in France and Ireland. Occasional papers in education and lifelong learning: an international journal, 5(1-2), 84-93.

Payne, J. (2008). Sector skills councils and employer engagement delivering the 'employerled'skills agenda in England. Journal of education and work, 21(2), 93-113.

Payne, J., \& Keep, E. (2011). One step forward, two steps back? Skills policy in England under the coalition government. SKOPE research paper, 102.

Rauner, F., \& Maclean, R. (Eds.). (2008). Handbook of technical and vocational education and training research. New York: Springer.

Rauner, F., \& Wittig, W. (2013). Differences in the Organisation of Apprenticeship in Europe: Findings of a Comparative Evaluation Study. In L. Deitmer, U. Hauschildt, F. Rauner \& H. Zelloth (Eds.), The architecture of innovative apprenticeship (pp. 243-256). Springer.

Saurugger, S. (2007). France. In F. Traxler \& G. Huemer (Eds.), Handbook of business interest associations, firm size and governance: A comparative analytical approach (pp. 122-140). New York: Routledge.

UKCES. (2011). UK sector skills councils - Annual performance report. April 2010 to March 2011.

Wolf, A. (2011). Review of vocational education: the Wolf report.

Wyse, D., Hayward, L., \& Pandy, J. (Eds.). (2015). The sage handbook of curriculum, pedagogy and assessment ( $1^{\text {st }}$ edition). Thousand Oaks, CA: SAGE Inc. 


\section{Biographical Note}

Jörg Markowitsch, Dr. phil, Dipl-Ing., is senior partner at 3s, Vienna, Austria. His areas of research include workplace learning, skills acquisition and development, skills intelligence as well as cross-country comparative research on vocational education and training and European education policy.

Günter Hefler, Dr. phil., is senior researcher and project manager at 3s, Vienna, Austria. His areas of research include workplace learning and training in organisations, adult learning, as well as cross-country comparative research on institutional processes connected to Lifelong Learning, skill formation and employment systems. 